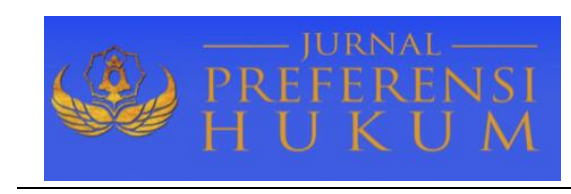

Jurnal Preferensi Hukum | ISSN: XXXX | E-ISSN: XXXX

Vol. 1, No. 2 - September 2020, Hal. 33-36| Available Online at https://www.ejournal.warmadewa.ac.id/index.php/juprehum

DOI: http://doi.org/10.22225/jph.v1i2.2339.33-36

\title{
AKIBAT HUKUM DARI WANPRESTASI DALAM TRANSAKSI JUAL BELI SECARA INSTAGRAM
}

\author{
Ryan Prastya Mariata Putra, Ida Ayu Putu Widiasti, Ni Made Puspasutari Ujianti \\ Fakultas Ilmu Hukum Universitas Warmadewa, Denpasar - Bali, Indonesia
}

\begin{abstract}
Abstrak
Pengaruh globalisasi yang terjadi saat ini telah membuat teknologi informasi dan komunikasi menjadi sesuatu yang sangat penting bagi masyarakat karena menghadirkan suatu dunia tanpa batas, jarak, ruang dan waktu. Hal tersebut telah membuat perubahan atas pola dan gaya hidup masyarakat serta mengubah kehidupan sosial, ekonomi, budaya, keamanan dan penegakan hukum. Penelitian ini dilakukan dengan tujuan mendeskripsikan bagaimana hak dan kewajiban para pihak dalaam kesepakatan niaga secara Instagram dan apa akibat hukum dari kealfaan pada kesepakatan niaga secara Instagram. Penelitian ini dilakukan dengan menggunakan metode penelitian hukum normatif. Hasil penelitian ini menunjukkan bahwa hak dan kewajiban para pihak dalam perikatan secara instragram sudah diatur secara jelas dalam UU PK. Konsumen dan pelaku usaha memiliki hak dan kewajibannya masing-masing. Selain itu, akibat hukum bagi debitur/pihak yang mempunyai kewajiban melaksanakan prestasi dalam perikatan tetapi melakukan kealfaan, yaitu: ia harus membayar ganti kerugian yang diderita oleh kreditur/pihak yang mempunyai hak menerima prestasi (vide Pasal 1243 KUHPerdata); ia harus menerima putusan perikatan disertai dengan pembayaran ganti kerugian (vide Pasal 1267 KUHPerdata); ia harus menerima peralihan resiko sejak saat terjadinya kealfaan (vide Pasal 1237 ayat (2) KUHPerdata); dan ia harus membayar biaya perkara jika diperkarakan di pengadilan (vide Pasal 181 ayat (1) HIR).
\end{abstract}

Kata Kunci: Kealfaan; Media Daring; Perikatan Kesepakatan Niaga

\begin{abstract}
The influence of globalization that occurs today has made information and communication technology became something very important for society because it presents a world without boundaries, distance, space, and time. This has made changes to the lifestyles of the people as well as changed the social, economic, cultural, security, and law enforcement. This research was conducted with the aim of describing the rights and obligations of the parties in an Instagram trade agreement and the legal consequences of negligence on an Instagram trade agreement. This research was conducted using normative legal research methods. The results of this study showed that the rights and obligations of the parties to the engagement on Instagram are regulated in the PK Law. Consumers and business actors have their respective rights and obligations. In addition, the legal consequences for a debtor/party who has the obligation to perform in the engagement but has committed negligence, namely: he must pay compensation suffered by the creditor/party who has the right to receive achievement (vide Article 1243 of the Civil Code); he must accept the decision of the engagement accompanied by payment of compensation (vide Article 1267 of the Civil Code); he must accept the transfer of risk from the moment of failure (vide Article 1237 paragraph (2) of the Civil Code); and he must pay court fees if litigated in court (vide Article 181 paragraph (1) HIR).
\end{abstract}

Keywords: Fairness; Online Media; Trade Agreement

\section{PENDAHULUAN}

Perkembangan jaman yang bergerak saat ini di era globaliasasi memberikan pengaruh pesat pada teknologi informasi dan komunikasi yang mendudukan pada letak yang penting bagian gaya hidup masyarakat sekarang ini karena dapat menyambungkan setiap orang di dunia tanpa adanya batasan ruang, waktu, maupun jarak. Inilah yang dimaksudkan dengan jejaring daring (Asnawi, 2004). Teknologi informasi dan komunikasi yang tumbuh meningkat saat ini telah banyak menyederhanakan pemakainya itu sendiri. Misalnya, kemajuan jejaring daring yang banyak diuntungkan untuk macam kegiatan misalnya pada kegiatan kesepakatan niaga. Salah satu jejaring sosial yang saat ini digemari untuk kesepakatan niaga tentunya secara jejaring Instagram. Model ini menjadi alternatif yang 
menarik dan sangat digemari oleh pembeli sekarang ini (Augustinah \& Widayati, 2019; Badrulzaman, 2001; Saleh \& Pitriani, 2018).

Di dalam Pasal 1 angka 24 UU No 7 Tahun 2014 terkait kesepakatan niaga daring dikatakan bahwasanya bentuk kesepakatan niaga mempergunakan jejaring daring pada perangkat dan prosedur secara elektronik. Pada umumnya, dalaam model kesepakatan niaga secara daring ini para pihak hanya melakukan persetujuan atas isi perikatan tanpa mengikuti pengaturan mengenai perikatan yang ada di Indonesia. Ketentuan Pasal 1320 KUH Perdata yang menyebutkan bahwa suatu perikatan tertulis dapat dikatakan sah apabila sudah terpenuhinya syarat subjektif dan objektif. Intinya pada model kesepakatan niaga daring ini adalah setiap pihak mempunyai hak dan kewajiban. Dalam hal ini penjual memiliki kewajiban memberikan informasi yang benar dan menawarkan produk yang diperbolehkan oleh peraturan hukum yang berlaku kepada pembeli.

Adanya beberapa hal keuntungan yang dirasakan oleh pihak pembeli maupun pihak penjual sehingga lebih nyaman mengadakan kesepakatan niaga secara daring ini. Ini disebabkan oleh biaya promosi yang dikeluarkan dapat lebih murah, produk dapat disaksikan selama seharian penuh oleh siapapun dan kapanpun, dan penjual juga dapat menjalankan bidang usahanya dengan lebih fleksibel dan santai karena dapat dilakukan saat sedang santai sekalipun.Tata cara menawarkan pada kegiatan kesepakatan niaga secara Instagram dilakukan dengan cara penjual mempergunakan akun Instagram nya untuk menunjukkan produk yang dijual pada halaman timeline Instagram calon pembelinya dan diikuti dengan penerimaan oleh pihak pembeli. Penjualan di Instagram ini menggunakan sistem penawaran dan interaksi yang mudah dilakukan sehingga memunculkan banyak ketertarikan peminat untuk melakukan kegiatan kesepakatan niaga itu secara media Instagram ini (Indrajit, 2002).

Namun dari hal ini tidak dipungkiri dapat menimbulkan suatu risiko yang ditimbulkan pada kegiatan kesepakatan niaga ini. Penyebabnya tidak lain adalah kesepakatan niaga yang seharusnya adanya bentuk pertemuan antara penjual dan pembeli sebagaimana pada model kesepakatan niaga konvensional tidak lagi akan dilakukan. Pihak penjual dan pembeli akan hanya melakukan kegiatan kesepakatan niaga menggunakan daring seperti Instagram dan yang lainnya hanya didasarkan atas rasa kepercayaan satu sama lain tanpa disertai dengan suatu perikatan tertulis (Faisal \& Rohmiyati, 2017; Pangestu, 2019). Keadaan semacam inilah yang akan menimbulkan akibat hukum dan semua resikonya. Contohnya, adanya sebuah tindakan ingkar janji oleh salah satu pihak. Lalu bagaimana pertanggung jawaban jika ada yang melakukan sengaja kealfaan ini? Dan masalah yang lain seperti tak adanya kewajiban pihak penjual untuk mengkonfirmasi kepembeli. Akibat dari ingkar janji ini yang terjadi nantinya akan ada suatu perselisihan kesepakatan niaga secara daring antara kedua belah pihak.

Berdasarkan latar belakang tersebut di atas maka penelitian ini dilakukan dengan tujuan mendeskripsikan bagaimana hak dan kewajiban para pihak dalaam kesepakatan niaga secara Instagram dan apa akibat hukum dari kealfaan pada kesepakatan niaga secara Instagram.

\section{METODE PENELITIAN}

Penulisan dalaam penelitian memakai jenis penelitian normatif. Penelitian normatif dilakukan dengan melihat peristiwa/perbuatan hukum yang ada di dalaam suatu masyarakat terkait dengan perikatan kesepakatan niaga secara sistem daring di Indonesia dan melihat UU, peraturan hukum serta sistem hukum yang berkenaan dengan permasalahan dalaam penelitian ini. Pendekatan dilakukan dengan melakukan pendekatan UU, dengan melihat ilmu hukum yang ada yaitu peraturan UU yang berlaku tentang permasalahan pada penelitian ini (Soekanto \& Mamudji, 2007).

Adapun sumber bahan hukum berasal dari sumber bahan hukum primer yakni peraturan UU, sumber bahan hukum sekunder yakni buku-buku, bahan hukum tertulis yang lainya, dan sumber bahan hukum tersier yaitu book hukum yang dapat membantu pemahaman dalaam menganalisa serta memahami permasalahan, seperti literatur, kamus hukum dan sumber lain yang sesuai. Pengumpulan bahan hukum dilakukan dengan mengumpulkan, mengkaji, dan mengolah bahan-bahan kepustakaan secara deskriptif dan argumentatif dengan menggambarkan kondisi permasalahan dan menemukan penyelesaian secara bahan kesepakatan niaga bahan hukum yang telah dikumpulkan. 


\section{HASIL PENELITIAN DAN PEMBAHASAN}

\section{Hak dan Kewajiban Para Pihak dalam Perikatan secara Instagram}

Dalam sebuah perikatan secara Instagram, ada dua pihak yang telibat, yaitu: pembeli dan penjual. Masing-masing pihak memiliki hak dan kewajiban yang berbeda. Hak pembeli atau konsumen diatur dalam pasal 4 Undang-undang Nomor 8 Tahun 1999 Tentang Perlindungan Konsumen (selanjutnya disebut dengan UU PK). Pasal ini menyatakan bahwa konsumen berhak memiliki rasa kenyamanan, keamanan, dan keselamatan dalam mengkonsumsi barang dan/atau jasa. Konsumen juga berhak untuk memilih dan mendapatkan barang dan/atau jasa sesuai dengan nilai tukar dan kondisi serta jaminan yang dijanjikan. Selanjutnya, pembeli harus diberi informasi yang benar, jelas, dan jujur mengenai kondisi dan jaminan barang dan/atau jasa. Dan, konsumen memiliki beberapa hak lain, yaitu: hak untuk didengar pendapat dan keluhannya atas barang dan/atau jasa yang digunakan; hak untuk mendapat advokasi, perlindungan, dan upaya penyelesaian sengketa perlindungan konsumen secara patut; hak untuk mendapat pembinaan dan pendidikan konsumen; hak untuk diperlakukan atau dilayani secara benar dan jujur serta tidak diskriminatif; hak untuk mendapatkan kompensasi, ganti rugi dan/atau penggantian, apabila barang dan/atau jasa yang diterima tidak sesuai dengan perjanjian dan tidak sebagaimana mestinya; dan hak yang diatur dalam ketentuan peraturan perundang-undangan lainnya.

Selain memiliki hak, konsumen juga memiliki kewajiban dalam sebuah perikatan. Hal ini diatur dalam Pasal 5 UU PK. Pasal ini menjelaskan bahwa kewajiban konsumen adalah membaca atau mengikuti petunjuk informasi dan prosedur pemakaian atau pemanfaatan barang dan/atau jasa demi keamanan dan keselamatan. Konsumen juga harus beriktikad baik dalam melakukan transaksi pembelian barang dan/atau jasa. Selain itu pembeli wajib membayar sesuai dengan nilai tukar yang disepakati, dan mengikuti upaya penyelesaian hukum sengketa perlindungan konsumen secara patut.

Di samping itu, penjual atau pelaku usaha juga memiliki hak dan kewajiban. Hak pelaku usaha diatur dalam Pasal 6 UU PK. Pasal ini memaparkan bahwa hak pelaku usaha berhak untuk menerima pembayaran yang sesuai dengan kesepakatan mengenai kondisi dan nilai tukar barang dan/atau jasa yang diperdagangkan. Dia juga berhak untuk mendapat perlindungan hukum dari tindakan konsumen yang beriktikad tidak baik. Hak-hak lain yang dimiliki oleh pelaku usaha adalah hak untuk melakukan pembelaan diri sepatutnya di dalam penyelesaian hukum sengketa konsumen, hak untuk rehabilitasi nama baik apabila terbukti secara hukum bahwa kerugian konsumen tidak diakibatkan oleh barang dan/atau jasa yang diperdagangkan, dan hak-hak yang diatur dalam ketentuan peraturan perundangundangan lainnya.

Seperti halnya konsumen, pelaku usaha juga memiliki kewajiban yang dirumuskan dalam pasal 7 UU PK. Pelaku usaha harus beritikad baik dalam melakukan kegiatan usahanya. Dia wajib memberikan informasi yang benar, jelas, dan jujur mengenai kondisi dan jaminan barang dan/atau jasa serta memberi penjelasan penggunaan, perbaikan, pemeliharaan. Pelaku usaha juga memiliki kewajiban untuk memperlakukan atau melayani konsumen secara benar dan jujur serta tidak diskriminatif. Kewajiban lainnya adalah menjamin mutu barang dan/atau jasa yang diproduksi dan/atau diperdagangkan berdasarkan ketentuan standar mutu barang dan/atau jasa yang berlaku, memberi kesempatan kepada konsumen untuk menguji dan/atau mencoba barang dan/atau jasa tersebut serta memberi jaminan dan/atau garansi atau barang yang dibuat dan/atau diperdagangkan, dan memberi kompensasi, ganti rugi, dan/atau menggantian apabila barang dan/atau jasa yang diterima atau dimanfaatkan konsumen tidak sesuai dengan perjanjian.

\section{Akibat Hukum dari Kealfaan pada Kesepakatan Niaga secara Instagram}

Kealfaan Perikatan berarti prestasi buruk yang timbul dari adanya perikatan yang dibuat oleh satu orang/lebih dengan satu orang/lebih lainnya. Kealfaan pada perikatan dikategorikan ke dalaam perbuatan kesepakatan niaga, yaitu: tidak melakukan apa yang disanggupinya; melaksanakan apa yang dijanjikannya, tetapi tidak sebagaimana yang dijanjikan; melakukan apa yang dijanjikannya tetapi terlambat; dan melakukan sesuatu yang menurut perikatan tidak boleh dilakukannya.

Akibat hukum bagi debitur/pihak yang mempunyai kewajiban melaksanakan prestasi dalam perikatan tetapi melakukan kealfaan, yaitu: ia harus membayar ganti kerugian yang diderita oleh kreditur/pihak yang mempunyai hak menerima prestasi (vide Pasal 1243 KUHPerdata); ia harus menerima putusan perikatan disertai dengan pembayaran ganti kerugian (vide Pasal 1267 KUHPerdata); ia harus menerima peralihan resiko sejak saat terjadinya kealfaan (vide Pasal 1237 ayat 
(2) KUHPerdata); dan ia harus membayar biaya perkara jika diperkarakan di pengadilan (vide Pasal 181 ayat (1) HIR).

\section{SIMPULAN DAN SARAN}

\section{Simpulan}

Berdasarkan hasil dan pembahasan yang telah dipaparkan di atas, ada beberapa simpulan yang dapat dibuat, yaitu: pertama, hak dan kewajiban para pihak dalam perikatan secara instragram sudah diatur secara jelas dalam UU PK. Konsumen dan pelaku usaha memiliki hak dan kewajibannya masingmasing. Kedua, Akibat hukum bagi debitur/pihak yang mempunyai kewajiban melaksanakan prestasi dalam perikatan tetapi melakukan kealfaan, yaitu: ia harus membayar ganti kerugian yang diderita oleh kreditur/pihak yang mempunyai hak menerima prestasi (vide Pasal 1243 KUHPerdata); ia harus menerima putusan perikatan disertai dengan pembayaran ganti kerugian (vide Pasal 1267 KUHPerdata); ia harus menerima peralihan resiko sejak saat terjadinya kealfaan (vide Pasal 1237 ayat (2) KUHPerdata); dan ia harus membayar biaya perkara jika diperkarakan di pengadilan (vide Pasal 181 ayat (1) HIR).

\section{Saran}

Selain simpulan, ada beberapa saran yang perlu disampaikan sesuai dengan hasil penelitian ini, yaitu: sosialisasi Perundangan ITE perlu dilakukan sehingga masyarakat dapat memahami dan mengetahui perihal tentang keabsahan perikatan kesepakatan niaga secara media daring tersebut.

Para pihak dalam perikatan kesepakatan niaga harus menerima hak dan melakukan kewajibannya sesuai dengan UU PK yang berlaku sehingga permasalahan tidak akan muncul.

\section{DAFTAR PUSTAKA}

Asnawi, H. F. (2004). Transaksi Bisnis e-commerce Perspektif Islam. Yogyakarta: Magistra Insania Press.

Augustinah, F., \& Widayati. (2019). Pemanfaatan Media Sosial sebagai Sarana Promosi Makanan Ringan Kripik Singkong di Kabupaten Sampang. DIALEKTIKA: Jurnal Ekonomi Dan Ilmu Sosial, 4(2), 1-20.

Badrulzaman, M. D. (2001). Kompilasi Hukum Perikatan. Bandung: Aditya Bakti.

Faisal, I. A., \& Rohmiyati, Y. (2017). Analisis Pemanfaatan Media Instagram sebagai Promosi Perpustakaan Provinsi Jawa Tengah. Jurnal Ilmu Perpustakaan, 6(4), 281-290.

Indrajit, R. E. (2002). E-Commerce: Strategi dan Konsep Bisnis di Dunia Maya.

Pangestu, R. L. (2019). Transaksi Jual Beli melalui Instagram Ditinjau Menurut Kitab UndangUndang Hukum Perdata. Jurnal Privat Law, 7(2), 275-282.

Saleh, G.-, \& Pitriani, R. (2018). Pengaruh Media Sosial Instagram dan WhatsApp Terhadap Pembentukan Budaya “Alone Together.” Jurnal Komunikasi, 10(2), 103-114.

Soekanto, S., \& Mamudji, S. (2007). Penelitian Hukum Normatif: Suatu Tinjauan Singkat. 